\title{
TÁRSASÁGI HÍREK
}

\author{
JUHÁSZ ERIKA
}

\section{BESZÁMOLÓ A MAGYAR BIZANTINOLÓGIAI TÁRSASÁG 2017. ÉVI TEVÉKENYSÉGÉRŐL}

A Magyar Bizantinológiai Társaság 2017-ben is folytatta felolvasóüléseinek szervezését. A meghívott előadók között megjelentek mind magyar, mind külföldi kutatók, s az előadások tárgyának kiválasztásánál is sokszínűségre törekedtünk. A rendezvényeken az alábbi előadások hangzottak el:

$$
\text { 2017. február } 20 .
$$

Glaser Tamás: Hazafiak és renegátok - görög identitások a késő bizánci és posztbizánci korban

Szász Géza (Szegedi Tudományegyetem): Van-e az útnak története? A konstantinápolyi út a magyar kutatásban

$$
\text { 2017. május } 11 .
$$

Tóth Anna: Kolindálás és Ruszália - Róma és Bizánc mint a balkáni néphagyomány forrásai

Archimédesz Szidiropulosz (Magyarországi Görögök Kutatóintézete): 1956 Görög szemmel

$$
\text { 2017. június } 15 .
$$

Szabó Pál (Szegedi Tudományegyetem): Bizánci forrásaink tanúsága Nándorfehérvár 1440. évi oszmán-török ostroma vonatkozásában

Juhász Erika (ELTE EC Byzantium Központ): Tanúságtevők a Húsvéti krónikában 2017. október 16.

Peter Schreiner (professor emeritus: Universität zu Köln): Translatio studii: Byzanz als Vermittler von Wissen in den Westen 
2017. november 28 .

Hermann Harrauer (professor emeritus: Universität Wien; Papyrussamlung der Österreichischen Nationalbibliothek): Tod in Ägypten

Kötetbemutató: Philologia Nostra II. Kapitánffy István válogatott irásai (szerkesztette Farkas Zoltán és Mészáros Tamás). A kötetet bemutatta Mayer Gyula

2017. december 7 .

Filippo Ronconi (EHESS Paris): Migrations of Books - Books and Migrations. Miscellaneous Medical and Grammatical Manuscripts from Alexandria to Southern Italy

2017. december 13 .

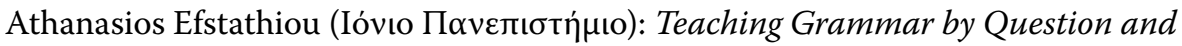
Answer in Early and Late Byzantium

A magyar és idegen nyelvű előadások mellett a Társaság és a magyar bizantinológia számára is különös jelentőséggel bírt a Philologia Nostra II. kötet novemberi bemutatása. ${ }^{1}$ Születésének (1932) és halálának (1997) évfordulóján tanítványai Kapitánffy István korábban különböző folyóiratokban, évkönyvekben elszórtan megjelent (és ma már nehezen hozzáférhető) tanulmányainak, tömör, lényegre törő összefoglalásainak és - mára szintén elérhetetlenné vált - bizánci irodalomtörténetének újraközlésével kívántak tisztelegni a nagyszerủ tanár, a jeles bizantinológus emléke előtt. A korábban idegen nyelven megjelent tanulmányok a kötetben magyar nyelven olvashatók. A kötet összeállítói remélik, hogy Kapitánffy Istvánnak a nemzetközi tudományosságban is újnak számító eredményei, módszertanilag is példaértékủ írásai ezáltal a szélesebb nyilvánossághoz is eljuthatnak.

Társadalmi kontextus a szövegkritika tükrében: Bizáncon innen és túl címü nemzetközi pályázatával nyerte el az NKFIH négy évre szóló támogatását az Eötvös Collegiumban működő Byzantium Központ. A pályázatban részt vevő kutatók a hagyományos történeti-filológiai módszerek alkalmazásának segítségével jelentős ókori, közép- és újkori szövegkorpuszok vizsgálatára és kritikai kiadására vállalkoztak, hogy ezek eredményeit felhasználva elemezzék és mutassák be a művek kortárs társadalmi (irodalmi és olvasói) közegét.

Újjáalakult a Magyar Tudományos Akadémia Klasszika-filológiai Tudományos Bizottságának Bizantinológiai Albizottsága. Az Albizottság három akadémiai ciklus-

1 Philologia Nostra II. Kapitánffy István válogatott tanulmányai. (Antiquitas - Byzantium - Renascentia 29). Szerk. Farkas Z. - Mészáros T. ELTE Eötvös József Collegium, Budapest 2017. A tanulmánykötet az alábbi linkről ingyenesen letölthető: http://byzantium.eotvos.elte.hu/wp-content/uploads/Kapitanffy.pdf. 
sal korábban alakult munkacsoportként, de az utóbbi két ciklusban Farkas Zoltán vezetésével albizottságként működött. A bizantinológiával érintkező tudományterületek képviselőit (régészek, történészek) a Magyar Bizantinológiai Társaság integrálja. Az Albizottság legfontosabb feladata a Magyar Bizantinológiai Társasággal együttműködve a nemzetközi kapcsolatok kiépítése, valamint a fiatal kutatók külföldi ösztöndíjakkal való támogatása, akik az elmúlt időszakban Párizsban, Münchenben, Berlinben, Bécsben és Oslóban folytathattak ösztöndíjas tanulmányokat. Az Eötvös Collegium három tagja szerzett eddig külföldön (Párizsban) bizantinológiai mesterszakos oklevelet. Magyarországon jelenleg négy doktori iskolában hat doktorandus készíti bizantinológiai tárgyú doktori értekezését.

A Magyar Bizantinológiai társaság évi rendes közgyủlésén (2017. december 14.) a tagság elfogadta az elnökség beszámolóját, valamint a pénzügyi beszámolót, majd jóváhagyta az új jelentkezők tagfelvételi kérelmét. 